\title{
Commodity Prices and Exchange Rate Volatility: Lessons from South Africa's Capital Account Liberalization
}

\author{
Rabah Arezki, Elena Dumitrescu, Andreas Freytag \\ and Marc Quintyn
}




\title{
IMF Working Paper
}

Institute for Capacity Development

\section{Commodity Prices and Exchange Rate Volatility: Lessons from South Africa's Capital Account Liberalization}

\section{Prepared by Rabah Arezki, Elena Dumitrescu, Andreas Freytag and Marc Quintyn ${ }^{1}$}

Authorized for distribution by Marc Quintyn

June 2012

\section{This Working Paper should not be reported as representing the views of the IMF.}

The views expressed in this Working Paper are those of the author(s) and do not necessarily represent those of the IMF or IMF policy. Working Papers describe research in progress by the author(s) and are published to elicit comments and to further debate.

\begin{abstract}
We examine the relationship between South African Rand and gold price volatility using monthly data for the period 1980-2010. Our main findings is that prior to capital account liberalization the causality runs from South African Rand to gold price volatility but the causality runs the other way around for the post-liberalization period. These findings suggest that gold price volatility plays a key role in explaining both the excessive exchange rate volatility and current disproportionate share of speculative (short-run) inflows that South Africa has been coping with since the opening up of its capital account.
\end{abstract}

JEL Classification Numbers: F21, F31, F32, Q0.

Keywords: Exchange rate; volatility; commodities; financial flows.

Author's E-Mail Address: rarezki@imf.org; elena.dumitrescu@univ-orleans.fr; A.Freytag@wiwi.uni-jena.de; mquintyn@imf.org.

\footnotetext{
${ }^{1}$ This project was started when Freytag was a visiting scholar at the IMF Institute. Dumitrescu is from the University of Orléans and Maastricht University and Freytag is from the University of Jena as well as the University of Stellenbosch. The financial support from the Economic Research Forum is greatly acknowledged. The authors would like to thank Leslie Lipschitz, Mico Loretan, Rodney Ramcharan, Amadou Sy, Gavin Gray, Toshi Miyoshi, Ceyda Oner and the participants of the ESSA 2011 Meeting in Stellenbosch for helpful discussions.
} 


\section{Contents}

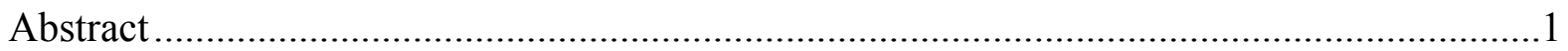

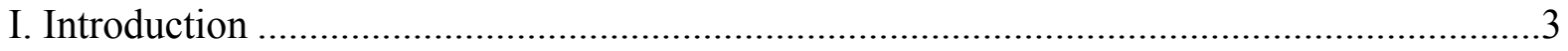

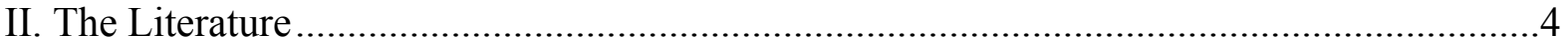

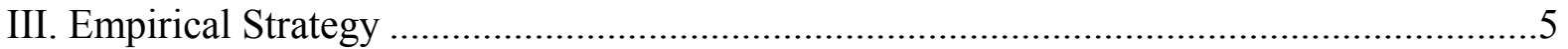

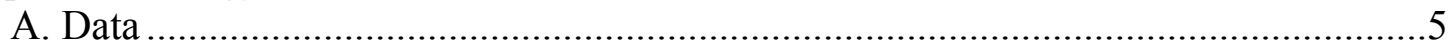

B. Time Series Properties and Econometric Techniques........................................6

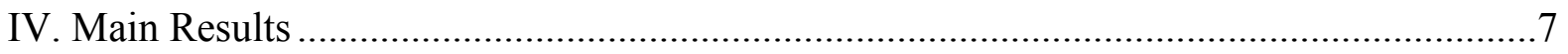

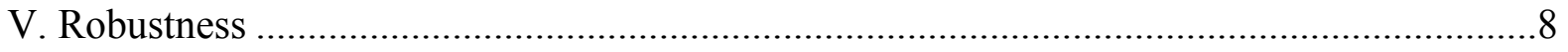

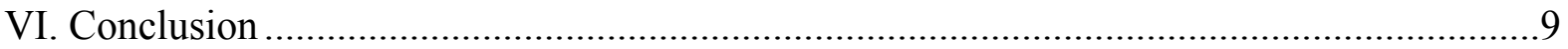

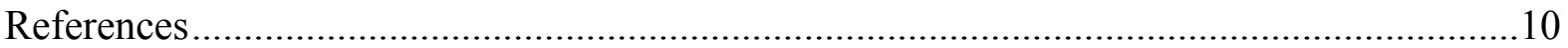

Tables

Table 1 Johansen Cointegration Test Results on Pre-Capital Account Liberalization ............14

Table 2 Johansen Cointegration Test Results on Post-Capital Account Liberalization ..........14

Table 3 Lagrange Multiplier Test for Residual Autocorelation........................................15

Table 4 VECM Results for Pre-Capital Account Liberalization Sample ...............................16

Table 5 Post-Capital Account Liberalization VECM Results ............................................17

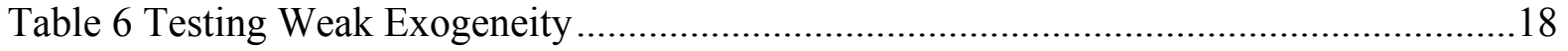

\section{Figures}

Figure 1. Evolution of Gold Prices and South Africa Rand Real Exchange Rate ..................13

Figure 2. Volatility of Gold Prices and South Africa Rand Real Exchange Rate ..................13 


\section{INTRODUCTION}

Commodity exporting countries face large terms of trade fluctuations which render their real exchange rate volatile. Increased volatility in the real exchange rate hurts the economy through its adverse consequences on private agents' consumption and investment decisions. ${ }^{2}$ South Africa, being the second largest producer of gold, is no exception to such exposure to volatility in the real exchange rate. Since the liberalization of the capital account - the financial rand was abolished in March 1995 - the South African Rand has experienced more frequent episodes of nominal and real exchange rate volatility than before (Ricci 2005). While Figure 1 shows that episodes of increases in gold prices have somewhat been followed by episodes of appreciations in the South African Rand, Figure 2 shows that, following South Africa's capital account liberalization, the action lies with the episodes of gold price volatility being followed by episodes of volatility in the South African Rand real exchange rate. ${ }^{3}$ Interestingly, South Africa has in the past decade also received an increasing portion of capital flows in the form of portfolio investments (Arezki, Faisal and Funke, 2007; Draper, Freytag and Voll, 2011). For instance foreign direct investment amounted to 0.3 percent of GDP in 2010 while portfolio flows amounted to 3 percent. ${ }^{4}$ To explain these patterns, some commentators have suggested an explanation based on global investors speculating on South African economic developments amid gold price volatility by investing in liquid South African assets. In the present paper, we examine the relationship between the volatility in gold price and real exchange rate in South Africa.

This paper aims at making two main contributions. First, it attempts to determine the direction of the causality between the volatility in both the gold price and the real exchange rate. It is important to note that we take into account both volatilities and not the joint movement of both prices. This is a novelty. Second, it explores to which extent liberalization of the capital account has changed the relationship between gold price and exchange rate volatility for South Africa. Answering these questions is not only relevant from an academic standpoint but also from a policy perspective. Indeed, given the very high level of volatility in commodity prices, it is important for resource rich countries in general to understand better the relationship between volatility in commodity prices and the fluctuations in their exchange rate. In addition, commodity exporting countries opening up their capital account may face a very different experience than other countries. Indeed, the volatile and potentially large source of revenue derived from commodity exports may magnify the impact of such capital account liberalization on the exchange rate.

\footnotetext{
${ }^{2}$ Small firms in particular may find it surprisingly costly to hedge against volatility in the exchange rate by using financial instruments. This inability to hedge against exchange rate fluctuations may have important consequences on the development of export oriented sectors. See Raddatz (2011) in this context.

${ }^{3}$ The heightened volatility in the South African Rand during the period 1982-1985 is related to political developments, i.e. the mounting political pressure by the international community combined with sanctions against the country due to apartheid which further led to erosion of the Rand's value.

${ }^{4}$ The data is from International Monetary Fund (2011).
} 
Our main finding is that prior to capital account liberalization the long-run causality runs from South African Rand to gold price volatility but the causality runs the other way around for the post-liberalization period. A policy inference reflects that following capital account liberalization in South Africa, the capital flow composition has been tilted toward portfolio investment (Fedderke, 2010).. The findings thus suggest that gold price volatility plays a key role in explaining both the excessive exchange rate volatility and the current disproportionate share of speculative (short-run) inflows that South Africa has been coping with since its capital account liberalization. The remainder of the paper is organized as follows. Section 2 discusses the basic literature and derives some hypotheses. Section 3 describes the data; Section 4 explains our estimation strategy; Section 5 discusses the main empirical results; and Section 6 concludes.

\section{THE LITERATURE}

This paper relates to three strands of literature. First, it connects more directly to the socalled commodity currency literature. This literature provides robust empirical evidence of the relationship between the level of the exchange rate and the level of commodity prices. The latter seems to drive the former. Chen and Rogoff (2003) provide early evidence of such a relationship for a selected number of resource-rich developed economies such as Australia, Canada and New Zealand. They find that the real exchange rates of Australia and New Zealand are driven by world commodity prices. The result is consistent with the analysis of Cashin, Cespedes and Sahay (2004), who provide additional evidence for a larger set of developing countries and commodities. In the specific case of South Africa, Frankel (2007) shows that an index of mineral prices is one, but not the only, important determinant of the real value of the Rand. This holds particularly in times when the Rand strongly appreciates in real terms (e.g. 2003-2006); Frankel identifies a Dutch disease problem. This is confirmed by Ngandy (2005) who surveys the literature on the relation between commodity prices and the real exchange rate of commodity exporting, mostly developing, countries.

Since we are interested in the consequences of institutional changes for the relation between the exchange rate and commodity prices too, we also refer to the literature on the impact of capital account liberalization on economic growth and financial crises. While the literature mentioned above has analyzed the effect of commodity prices on the real exchange rate, Cuddington and Liang (1998) look at the effects of different exchange rate regimes on commodity price volatility. Although they only use three types of exchange rate regimes, ${ }^{5}$ they show that real commodity prices are more volatile in flexible exchange rate regimes than in periods of fixed exchange rates. Dell Arrica et al. (2000) address the potential gains and risks of open capital markets by first looking at what classical economic theory suggests about the benefits of capital mobility and then examine the counterarguments arising from problems of incomplete information and other distortions. They show that the risks of removing international capital controls are similar to those associated with removing controls on domestic financial institutions. Henry (2007) reviews the evidence between capital account liberalization and economic growth. He finds that, contrary to what is often argued in

\footnotetext{
${ }^{5}$ See Levy-Yeyati and Sturzenegger (2002) for a more sophisticated differentiation of exchange rate regimes.
} 
the literature, capital account liberalization has effects consistent with the neoclassical theory in that it raises transitorily economic growth rather than permanently.

Finally, this paper also relates to the literature on macroeconomic volatility. This of course is a vast literature and we restrict ourselves to discussing the strand of research focused on analyzing the effects of commodity price volatility on macroeconomic trends. Drawing on several of their earlier papers, Aghion and Banerjee (2005) explore the various causal connections between the trend growth of output and the volatility of output around the trend, concluding from empirical cross-country evidence that volatility hurts growth. Along similar lines, Ramey and Ramey (1995) provide evidence that volatility in economic growth diminishes average growth in a sample of 92 countries as well as in a sample of OECD countries. Aghion, Bachhetta, Ranciere and Rogoff (2009) offer empirical evidence that real exchange rate volatility can have a significant impact on the long-term rate of productivity growth, but the effect depends on a country's level of financial development. Finally, also worth mentioning are the contributions on the effects of exchange rate volatility on trade and commodity prices (e.g. Bui and Pippenger 1990, Smith 1999, Gilbert 1989 and Raddatz 2011). Especially Gilbert's analysis is interesting, since he shows that commodity exporting countries can be hurt by US-dollar appreciations.

We contribute to this literature by focusing not on the first moment of the relationship between commodity price and real exchange rate but on the second moment namely their volatility, using South Africa as a case study. As stated earlier, South Africa, being the second largest producer of gold, is therefore exposed to volatility in real exchange rate. Importantly also, the liberalization of the capital account in March 1995 provides a quasinatural experiment to investigate the impact that such a change in institutional settings may have on the relationship between commodity price and exchange rate volatility.

\section{EMPIRICAL STRATEGY}

In the following, we systematically investigate the relationship between the volatility of commodity prices and the volatility of the South African Rand's real exchange rate both in the short- and long-run. Again, Figure 2 shows that episodes of gold price volatility have been followed by episodes of volatility in the South African Rand real exchange rate mainly after South Africa's capital account liberalization. Conceptually, commodity price volatility and exchange rate volatility pertains to transactions affecting both the current and the capital accounts. This relation may therefore be subject to changes when the institutional setting (e.g. capital controls) significantly changes, as has been the case in South Africa following the end of Apartheid in 1994. Some commentators have indeed suggested that the volatility in the South Africa Rand may results from global investors speculating on South African economic developments amid gold price volatility by investing in liquid South African assets.

\section{A. Data}

To compute our measure of international gold price volatility we use monthly data from UNCTAD Commodity Statistics covering the years 1979-2007. Our measure of price 
variation is the twelve month rolling window of the standard deviation of our international gold price index. We also construct a measure of real exchange rate volatility based on the real effective exchange rate (REER) combining monthly consumer price index data and the monthly nominal exchange rate from IMF (2010). The volatility measure is again the twelve month rolling window of the standard deviation of REER.

As for the choice of a break date corresponding to South Africa's capital account liberalization, we follow Farrell and Todani (2004) who state that the so-called financial Rand system was abolished in 1995 and exchange controls were also relaxed. It may well be argued that the institutional changes were not finished in 1995, but we assume that this year provides the most important positive shock for the South African economy with respect to its international relations.

\section{B. Time Series Properties and Econometric Techniques}

In this section, we analyze the statistical properties of the various series used in the empirical analysis. First, looking at the evolution of the two series it can be noticed that the volatility of the gold price is much lower than that of the real exchange rate, with a ratio of 1:16 (see figures 1 and 2). And more interestingly, the drop in volatility is even more visible after liberalization. At a theoretical level, this could be explained by the fact that real exchange rate volatility may, in general, depend on the size of both traded and nontraded sectors in the economy. It results that the capital controls have a clear impact on the evolution of this variable. At the same time, it seems there is a long-term one-for-one relationship between the price of gold and the general price level in the USA (Levin and Wright, 2006), which justifies why gold price volatility has been historically low. These findings are worth noting, as it can be argued that increased risk associated with volatility is likely to induce risk-averse agents to direct their resources to less risky economic activities.

Second, we test for unit roots by using the system ML estimator of Johansen $(1988,1991)$, which is a test for cointegration restrictions in a VAR representation. First, no unit root and no cointegration is found between REER and gold price volatility when taking the whole period from 1980 until 2007. However, it can be argued that such a long period (27 years) is subject to structural instability. Indeed, when splitting the sample in two, with 1995 as the breakpoint, we cannot reject the hypothesis that the series are integrated of order one over the two sub-samples. As discussed earlier, the split is motivated by the major institutional changes in the South African policy towards capital flows and exchange controls that took place in that year. Furthermore, the two time-series appear to be cointegrated in both pre and post liberalization sub-samples. Indeed, tables 1 and 2 provide evidence based on the Johansen cointegration test that we cannot reject the existence of a cointegration relationship between gold price and real exchange rate volatility. To be more precise, the trace-test indicates that there is one cointegration relationship between gold and real exchange rate volatility both before and after liberalization.

These results motivate the use of a Vector Error Correction Model (VECM) rather than Vector Autoregression (VAR). This approach allows us to isolate short and long run relationships between volatility in the gold price and in the real exchange rate. In turn, ignoring the cointegration relationship and using variables in difference in a VAR framework 
would lead to biased estimates, as only the short-term fluctuations would be taken into account in the analysis. ${ }^{6}$

Formally, we denote by $y_{t}$ the vector of gold and real exchange rate volatility. Since the two series are cointegrated, the VECM of order $p$ can be written as: ${ }^{7}$

$$
\Delta y_{t}=\delta+\Pi y_{t-1}+\sum_{i=1}^{p-1} \Phi_{i}^{*} \Delta y_{t-i}+\varepsilon_{t}
$$

where $\Delta$ is the differencing operator, such that $\Delta y_{t}=y_{t}-y_{t-1}, \Pi$ as well as the $\Phi_{i}^{*}$ are functions of the parameters of a VAR model for the variables in level, and $p$ is the order of this VAR model. The error correction term $\Pi y_{t-1}$ provides also a channel through which Granger causality can occur in addition to the traditional channel through lagged independent variables.

\section{Main Results}

In the following, we discuss the estimation results of the VECM model described earlier. Table 3 reports the results of the Lagrange-multiplier (LM) test for autocorrelation in the residuals of vector error-correction models (before and after the liberalization). At the 10\% level, we cannot reject the null hypothesis that there is no autocorrelation in the residuals for any of the orders tested. Since these results indicate that there is no evidence of model misspecification we proceed with the analysis of the estimation results.

Tables 4 and 5 summarize our main results linking the volatility in gold price and real exchange rate volatility. First, we take a look at the short run. Short-run effects are given by the coefficients of the lags $(t-1, t-2)$ of the change in the REER and the gold price (D_REER volatility and D_Gold Price volatility respectively). As can be seen in Table 4, before 1995 movements in the REER and in the gold price are affected by their own dynamics but do not affect each other. The coefficients associated with the lagged gold price volatility are not significant in the equation for REER volatility (see panel 1) and vice versa. ${ }^{8}$ This restriction, that is, that REER and gold price volatility are affected by their own dynamics but do not affect each other in the short run, is not observed anymore following the capital account liberalization that is after 1995. Table 5 shows that in the short run the lagged coefficients of REER and gold price volatility are statistically significant in both panels but coefficients associated with cross-terms are not, except for the second lag of the REER in first difference in the equation of gold price volatility in first difference. These results suggest that, in the short run, there is no statistically significant relationship between gold price and real

\footnotetext{
${ }^{6}$ See West and Cho (1989) for a principal analysis of different estimation models of exchange rate volatility

${ }^{7}$ The order of the VECM is determined using standard information criteria (AIC and HQ) and such that the residuals of the model are not autocorrelated.

${ }^{8}$ The third column (z-statistic) reflects the t-student distributions.
} 
exchange rate volatility and the absence of such statistically significant relationship has been only slightly altered by South Africa's capital account liberalization. This finding corroborates the initial observation that the two series are only marginally correlated, with a correlation coefficient that increases from nearly 0 to 0.2 after the liberalization.

Next, we consider the long run relationship. The long run effect is given by the coefficient of the error correction term (ER). In the pre-1995 period, the long-run relationship between REER and gold price volatility is significant only in the equation of gold price volatility (See Table 4). This finding indicates that there is a long run effect of REER volatility on gold price volatility but not the other way around. Indeed, the error correction coefficient in the first panel of Table 4 provides evidence that REER volatility does not adjust in the short run to the long term relationship. We conclude that there is no long run effect of gold price volatility on REER volatility at conventional statistical confidence levels. In contrast, in the second panel of Table 4 the coefficient of the correction term EC suggests that the REER volatility causes gold price volatility in the long run. The long-run coefficients, defining the cointegrating relationship, are included in the third panel of Table 4. Along with the adjustment coefficients (ER) they ensure that REER volatility moves in the correct direction in order to bring the system back to 'equilibrium'. To complement this finding, we further perform some exogeneity tests. These tests confirm that we cannot reject the null hypothesis of exogeneity for REER but we can for gold price volatility (See the top part of Table 6). This implies that in the long term gold price volatility is driven by REER. These results are in contrast with the insights from a recent literature including Chen and Rogoff (2003), who suggest that the exchange rate is a good predictor of countries' main export commodity prices. One explanation is that the empirical evidence presented in Chen and Rogoff (2003) is based on a sample of mostly advanced countries where the capital accounts are open and therefore where financial flows, anticipating changes in commodity prices, move the exchange rates in commodity exporting countries.

After 1995, the cointegration vector indicates the presence of a long-run relationship between REER and gold price volatility, going from gold price volatility to REER volatility (Table 5). So, we find evidence that gold price volatility causes REER volatility in the long run. Panel 1 in Table 5 provides evidence that the error correction coefficient is statistically significant while it is not the case in panel 2. The cointegrating vector is displayed in panel 3. The weak exogeneity test confirms this finding, as we have to reject the null hypothesis of exogeneity for both REER and gold price volatility but more so for REER volatility (See the bottom part of Table 6). Hence, the results reveal that REER volatility rejoins the long-term equilibrium defined by gold price volatility much faster than the other variable. These results are consistent with an explanation based on the global investors speculating on South African economic developments amid gold price volatility by investing in liquid South African assets. Capital account liberalization brings about important challenges for commodity exporting countries, which may have adverse consequences on the rest of the economy including on the decision of investors facing heightened real exchange volatility.

\section{Robustness}

We conducted a number of robustness checks, which turn out to confirm the main results presented in this paper. First, we use different break dates, since it is by no means clear that 
the financial reforms in South Africa had their effects on capital markets immediately. We conduct robustness tests using respectively 1996 and 1997 as break dates, which does not change the results substantially. Secondly, we substitute the REER with a measure of volatility in sovereign bond yields by using Emerging Market Bond Index (EMBI) data available only from end 1990s (corresponding to the post account liberalization period). The rationale behind using the EMBI index is that it constitutes an important financial indicator of the creditworthiness of a given country which certainly relates to gold price levels that eventually affect government revenues. Analyzing the relationship between gold price and EMBI volatility is relevant especially because EMBI volatility may complicate the conduct of government and other agents' policy decisions. The series, namely gold price and EMBI volatility, are found to be non-stationary and cointegrated. We find that the cointegration relationship goes both ways but we find some evidence that the gold price affects EMBI volatility somewhat more than the other way around (the results are available upon request). Again, an open capital account may lend itself to more speculative flows invested in sovereign financial assets anticipating the economic impact of gold price (volatility). ${ }^{9}$

\section{Conclusion}

In this paper, we have studied the relationship between Rand-REER volatility and gold price volatility. Our preliminary results indicate that in the case of South Africa gold price volatility has become a more determining factor for Rand-REER volatility after the liberalization than before. This is an important result since increased REER volatility may have consequences on investment and trade. The dependence of the South African economy on gold and its price developments seems to become more important, in particular under open capital markets. Thus, the result adds to a long list of challenges for commodity exporting countries. The transmission of volatility from the gold price to the REER constitutes certainly a challenge that is likely to remain on the top of policy makers' agenda as commodity prices have entered an age of growing volatility. Indeed the perceived lack of safe assets at the onset of the financial crisis 2007-08 has engendered a flight to commodities, which has led to a sharp increase in the prices of the latter. We have provided evidence that commodity price volatility has had an impact on the volatility in the cost of borrowing for South Africa, in turn complicating the conduct of fiscal policy. Commodity exporting countries need to weigh the benefits and costs of capital account liberalization in the light of the potential heightened transmission between commodity price volatility and key variables such as the REER and borrowing costs. The raging debate as to whether capital controls may be appropriate in view of surges in capital inflows faced by a number of emerging markets may also benefit from considering the specific circumstances commodity exporting countries are facing and considering a focus on exchange rate volatility rather that its level.

\footnotetext{
${ }^{9}$ A wider range of commodities could be considered and the results compared with those characterizing smaller commodity producers, and non-commodity-producing countries with liberalized capital accounts. This is left for future research.
} 


\section{REFERENCES}

Aghion, Philippe and Abhijit Banerjee (2005). Volatility and Growth: The Clarendon Lectures in Economics. Oxford University Press, Oxford, UK.

Aghion, Philippe, Bacchetta, Philippe and Rancière, Romain \& Rogoff, Kenneth (2009), "Exchange rate volatility and productivity growth: The role of financial development," Journal of Monetary Economics, Elsevier, May, Vol. 56(4), pp. 494-513.

Arezki, Rabah, Ahmed Faisal and Norbert Funke (2007) "The composition of capital flows to South Africa," Journal of International Development, John Wiley \& Sons, Ltd., Vol. 19(2), pp. 275-294.

Bahmani-Oskooee, M. and S. Hegerty (2007), 'Exchange Rate Volatility and Trade Flows: A Review Article', Journal of Economic Studies, 34, 3, pp. 211-255.

Bui, Nhuong and John Pippenger (1990), Commodity Prices, Exchange Rates and their Relative Volatility, Journal of International Money and Finance, 9, pp. 3-20.

Cashin, Paul, Luis F. Cespedes and Ratna Sahay (2004), Commodity Currencies and the Real Exchange Rate, Journal of Development Economics, Elsevier, 75(1), pp. 239-268.

Chen, Yu-chin and Kenneth Rogoff (2003), Commodity Currencies, Journal of International Economics, Elsevier, 60(1), pp. 133-160.

Chen, Yu-Chin, Kenneth Rogoff and Barbara Rossi (2010), Can Exchange Rates Forecast Commodity Prices?, The Quarterly Journal of Economics, MIT Press, 125(3), pp. 1145-1194.

Cross, James H. (2003), Global Integration and Capital Account L in South Africa,in BIS Papers No 15., China's capital account liberalisation: international perspective, pp. 104-116.

Cuddington, John T. and Hong Liang (1998), Commodity Price Volatility across Exchange Rate Regimes, mimeo, Georgetown University.

Dell'Ariccia, Giovanni, Enrica Detragiache, Michael Mussa and Barry J. Eichengreen (1998), Capital Account Liberalization: Theoretical and Practical Aspects, IMF Occasional Papers 172, International Monetary Fund.

Draper, Peter, Andreas Freytag and Sebastian Voll (2011), Global Financial Crisis, Protectionism and Current Account Deficit - South Africa on the Brink?, World Economics, Vol. 12, No. 2, pp. 129-152. 
Farrell, G. N. and K. R. Todani (2004), Capital Flows, Exchange Control Regulations and Exchange Rate Policy: The South African Experience, OECD Seminar, Bond Exchange of South Africa.

Fedderke, Johannes, (2010), Sustainable Growth in South Africa, in Growth and Sustainability in Brazil, China, India, Indonesia and South Africa, OECD Publishing.

Frankel, Jeffrey (2007), On The Rand: Determinants Of The South African Exchange Rate, South African Journal of Economics, Economic Society of South Africa, 75, 3, pp. $425-441$.

Gilbert, Christopher L. (1989), The Impact of Exchange Rates and Developing Country Debt on Commodity Prices, The Economic Journal, pp. 773-784.

International Monetary Fund (2011), South Africa 2011 Article IV Consultation, IMF country report $11 / 258$.

Johansen, Sorensen, 1991, Estimation and Hypothesis-Testing of cointegration vectors in Gaussian Vector autoregressive models, Econometrica 59(6), pp. 1551-1580.

Levin, E.J., Wright, R.E. 2006, Short-run and Long-run Determinants of the Price of Gold. World Gold Council, Research Study No 32.

Peter Blair Henry (2007), "Capital Account Liberalization: Theory, Evidence, and Speculation," Journal of Economic Literature, American Economic Association, December, Vol. 45(4), pp. 887-935.

Levy-Yeyati, Eduardo and Federico Sturzenegger (2003): A de facto Classification of Exchange Rate Regimes: A Methodological Note, posted at http://www.aeaweb.org/aer/contents/ of American Economic Review, Vol. 93 (4).

Ngandu, S. (2005), Mineral Prices and the Exchange Rate: what does the Literature say, HSRC, mimeo.

Raddatz, Claudio (2011), "Over the hedge. Exchange Rate Volatility, Commodity Price Correlations, and the Structure of Trade," World Bank Policy Research Working Paper 5590, March.

Ramey, Garey and Ramey, Valerie A (1995), "Cross-Country Evidence on the Link between Volatility and Growth," American Economic Review, American Economic Association, December, Vol. 85(5), pp. 1138-51.

Ricci, Luca Antonio (2005), South Africa's Real Exchange Rate Performance", Ch.9 in PostApartheid South Africa: The First Ten Years, edited by Micheal Nowak and Luca Antonio Ricci, IMF, Washington, DC 2005. 
Smith, C. E. (1999), Exchange Rate Variation, Commodity Price Variation, and the Implications for International Trade, Journal of International Money and Finance, 18, pp. 471-491.

West, Kenneth D. and Dongchul Cho (1995), The Predictive Ability of Several Models of Exchange Rate Volatility, Journal of Econometrics, 69, pp. 367-391. 
Figure 1. Evolution of Gold Prices and South Africa Rand Real Exchange Rate $(1979$ - 2011)

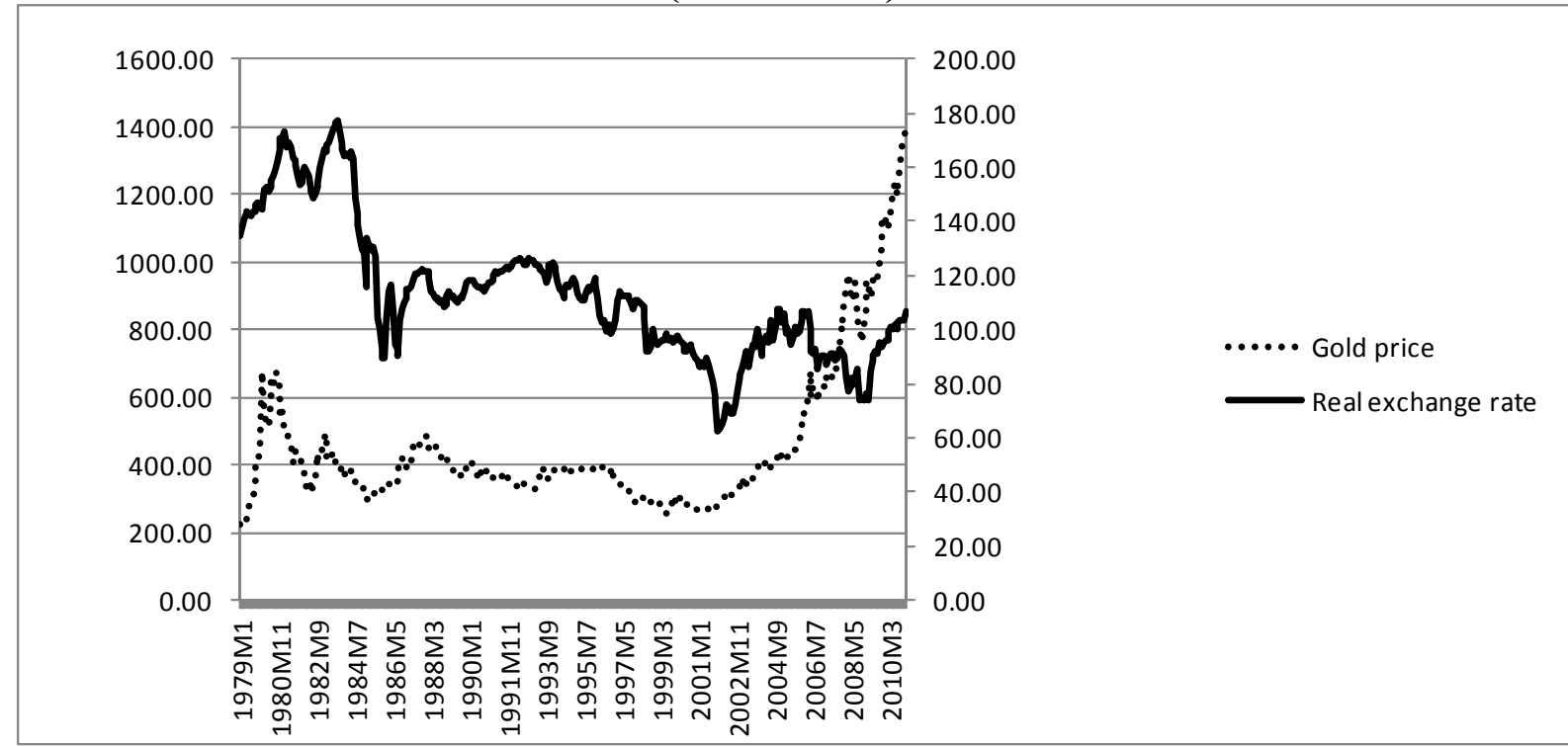

Source: Gold price data is from UNCTAD Commodity Statistics. Real exchange rate (REER) combines monthly consumer price index data and the monthly nominal exchange rate from IMF (2010).

Figure 2. Volatility of Gold Prices and South Africa Rand Real Exchange Rate (1979-2011)

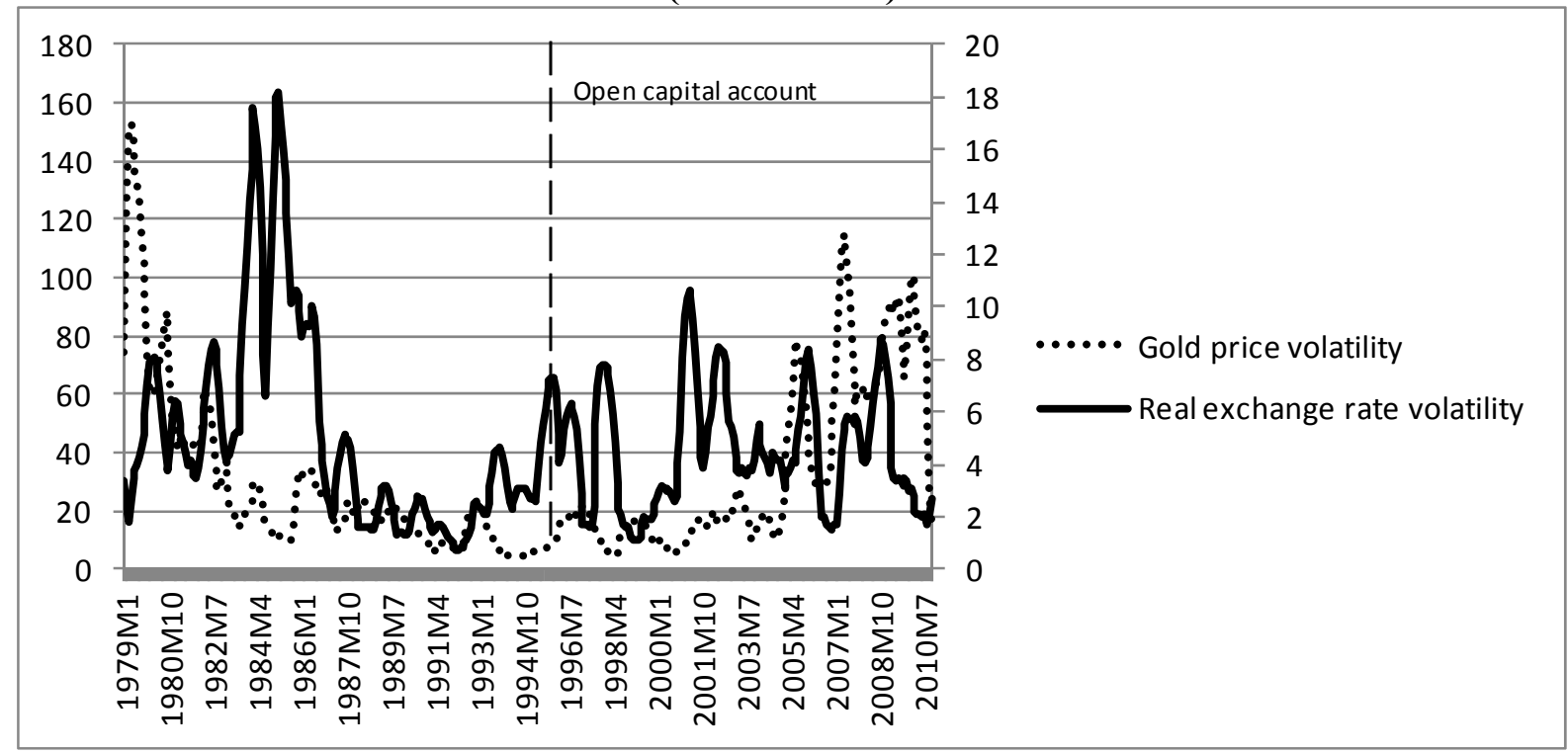

Source: Our measure of international gold price variation is the twelve month rolling window of the standard deviation of our international gold price index using gold price data from UNCTAD Commodity Statistics. The real effective exchange rate (REER) combines monthly consumer price index data and the monthly nominal exchange rate from IMF (2010). The REER volatility measure is the twelve month rolling window of the standard deviation of REER. 


\section{Table 1 Johansen Cointegration Test Results on Pre-Capital Account Liberalization Sample}

Trend: none

Number of obs $=181$

Lags $=5$

\begin{tabular}{llllll}
\hline maximum & & & & \\
rank & parameters & loglikelihood & eigenvalue & statistic & $\begin{array}{l}5 \% \\
\text { critical value }\end{array}$ \\
0.0000 & 16.0000 & -314.4047 & & 17.9881 & 12.530 \\
1.0000 & 19.0000 & -306.7603 & 0.0810 & $2.6993^{*}$ & 3.8400 \\
2.0000 & 20.0000 & -305.4106 & 0.0148 & & \\
\hline
\end{tabular}

Note: The null hypothesis of the trace test is the existence of a number of cointegration relations equal to the rank, versus the maximum rank (2 here). The critical value at a 5\% risk level is included, so that the null hypothesis is rejected if the test-statistics is larger than the critical value. 'Lags' is the optimal number of lags of the underlying VAR model, identified using information criteria.

\section{Table 2 Johansen Cointegration Test Results on Post-Capital Account Liberalization Sample}

Trend: none

Number of obs $=181$

Lags $=3$

maximum

rank

0.0000

parameters

loglikelihood

trace

$5 \%$

1.0000

8.0000

$-202.3277$

eigenvalue

statistic

critical value

2.0000

11.000

$-196.0045$

0.0675

13.354

12.530

12.0000

$-195.6508$

$0.7073 *$

3.8400

Note: The null hypothesis of the trace test is the existence of a number of cointegration relations equal to the rank, versus the maximum rank (2 here). The critical value at a 5\% risk level is included, so that the null hypothesis is rejected if the test-statistics is larger than the critical value. 'Lags' is the optimal number of lags of the underlying VAR model, identified using information criteria. 
Table 3 Lagrange Multiplier Test for Residual Autocorelation

(1979-1994)

\begin{tabular}{llll} 
lag & chi2 & df & Prob $>$ chi2 \\
\hline 1.0000 & 7.5759 & 4 & 0.1084 \\
6.0000 & 8.0892 & 4 & 0.0884 \\
12.0000 & 8.6740 & 4 & 0.0698 \\
18.0000 & 3.0007 & 4 & 0.5577 \\
24.0000 & 12.1413 & 4 & 0.0163
\end{tabular}

$\underline{(1995-2011)}$

\begin{tabular}{llll} 
lag & chi2 & df & Prob>chi2 \\
\hline 1.0000 & 0.5941 & 4 & 0.9637 \\
6.0000 & 12.8373 & 4 & 0.0121 \\
12.0000 & 9.4205 & 4 & 0.0514 \\
18.0000 & 8.6451 & 4 & 0.0706 \\
24.0000 & 7.2657 & 4 & 0.1225 \\
\hline Note: H0 - no autocorrelation at the specified lag order &
\end{tabular}

Note: HO - no autocorrelation at the specified lag order 
Table 4 VECM Results for Pre-Capital Account Liberalization Sample (1979 - 1994)

Panel 1

Dependent variable: D_REER Volatility

\begin{tabular}{lllll} 
& Coefficient & Std. Err. & Z-statistic & P-value \\
\hline EC & 0.0352 & 0.0724 & 0.4900 & 0.6260 \\
D_REER Volatility & & & \\
t-1 & 0.8159 & 0.0750 & 10.8800 & 0.0000 \\
t-2 & -0.1457 & 0.0970 & -1.5000 & 0.1330 \\
t-3 & 0.0076 & 0.0964 & 0.0800 & 0.9370 \\
t-4 & -0.1755 & 0.0744 & -2.3600 & 0.0180 \\
D_Gold Price Volatility & & & \\
t-1 & 0.0309 & 0.8485 & 0.0400 & 0.9710 \\
t-2 & -0.4208 & 1.1083 & -0.3800 & 0.7040 \\
t-3 & -0.2007 & 1.0649 & -0.1900 & 0.8510 \\
t-4 & -0.0400 & 0.6057 & -0.0700 & 0.9470 \\
\hline
\end{tabular}

\section{Panel 2}

Dependent variable: D_Gold Price Volatility

\begin{tabular}{lllll} 
& Coefficient & Std. Err. & Z-statistic & P-value \\
\hline EC & -0.0242 & 0.0063 & -3.8500 & 0.0000 \\
D_REER Volatility & & & \\
t-1 & 0.8504 & 0.0737 & 11.5400 & 0.0000 \\
t-2 & -0.3169 & 0.0963 & -3.2900 & 0.0010 \\
t-3 & 0.1380 & 0.0925 & 1.4900 & 0.1360 \\
t-4 & -0.0936 & 0.0526 & -1.7800 & 0.0750 \\
D_Gold Price Volatility & & & \\
t-1 & -0.0058 & 0.0065 & -0.9000 & 0.3710 \\
t-2 & 0.0018 & 0.0084 & 0.2200 & 0.8280 \\
t-3 & 0.0031 & 0.0084 & 0.3700 & 0.7140 \\
t-4 & -0.0003 & 0.0065 & -0.0500 & 0.9630 \\
\hline
\end{tabular}

\section{Panel 3}

\section{Coefficients of the long-run relation}

$$
\text { Coefficient Std. Err. }
$$

Z-statistic

P-value

\begin{tabular}{|c|c|c|c|c|}
\hline $\begin{array}{l}\text { Gold Price } \\
\text { Volatility }\end{array}$ & 1.0000 & & . & . \\
\hline REER & & & & \\
\hline Volatility & -0.0462 & 0.0239 & 1.9600 & 0.0500 \\
\hline
\end{tabular}

Note : The table includes the value and the statistical significance of the short run coefficients of the VECM model as well as the ones of the error correction term (EC). 
Table 5 Post-Capital Account Liberalization VECM Results (1995 - 2011) Panel 1

\section{Dependent variable: D_REER Volatility}

\begin{tabular}{lcccc} 
& Coefficient & Std. Err. & z-statistic & P-value \\
\hline EC & -0.0313 & 0.0109 & -2.8800 & 0.0040 \\
D_REER Volatility & & & \\
t-1 & 0.8162 & 0.0727 & 11.2200 & 0.0000 \\
t-2 & -0.1386 & 0.0742 & -1.8700 & 0.0620 \\
D_Gold Price Volatility & & & \\
t-1 & 0.2225 & 1.2613 & 0.1800 & 0.8600 \\
t-2 & -0.0490 & 1.2941 & -0.0400 & 0.9700 \\
\hline
\end{tabular}

Panel 2

\section{Dependent variable: D_Gold Price Volatility}

\begin{tabular}{lcccc} 
& Coefficient & Std. Err. & z-statistic & P-value \\
\hline EC & 0.0014 & 0.0006 & 2.1900 & 0.0280 \\
D_REER Volatility & & & \\
t-1 & 0.0070 & 0.0042 & 1.6500 & 0.1000 \\
t-2 & -0.0116 & 0.0043 & -2.6800 & 0.0070 \\
D_Gold Price Volatility & & & \\
t-1 & 0.7370 & 0.0736 & 10.0100 & 0.0000 \\
t-2 & -0.0153 & 0.0755 & -0.2000 & 0.8400 \\
\hline
\end{tabular}

\section{$\underline{\text { Panel } 3}$}

\section{Coefficients of the long-run relation}

\begin{tabular}{|c|c|c|c|c|}
\hline & Coefficient & Std. Err. & Z-statistic & P-value \\
\hline REER & & & & \\
\hline $\begin{array}{l}\text { Volatility } \\
\text { Gold Price }\end{array}$ & 1.0000 & & . & . \\
\hline Volatility & -12.299 & 2.7483 & -4.4800 & $<0.001$ \\
\hline
\end{tabular}




\section{Table 6 Testing Weak Exogeneity}

\section{(1979-1994)}

\begin{tabular}{llll} 
Equation & Parms & \multicolumn{1}{c}{ chi2 } & P $>$ chi2 \\
\hline D_rvolat & 1 & 0.2371 & 0.6263 \\
D_gvolat & 1 & 14.8384 & 0.0001 \\
& & & \\
& $\underline{(1995-2011)}$ &
\end{tabular}

\begin{tabular}{llcc} 
Equation & Parms & chi2 & $\mathrm{P}>$ chi2 \\
\hline D_rvolat & 1 & 8.2769 & 0.0040 \\
D_gvolat & 1 & 4.8090 & 0.0283 \\
\hline \multicolumn{4}{c}{ Note: H0- weak exogeneity of the variable }
\end{tabular}

